\title{
Immune-Glutamatergic Dysfunction as a Central Mechanism of the Autism Spectrum Disorders
}

\author{
R.L. Blaylock ${ }^{1}$ and A. Strunecka*,2 \\ ${ }^{1}$ Belhaven College, Jackson, Mississippi, USA \\ ${ }^{2}$ Institute of Medical Biochemistry, Laboratory of Neuropharmacology, 1st Faculty of Medicine, Charles University in \\ Prague, Prague, Czech Republic
}

\begin{abstract}
Despite the great number of observations being made concerning cellular and the molecular dysfunctions associated with autism spectrum disorders (ASD), the basic central mechanism of these disorders has not been proposed in the major scientific literature. Our review brings evidence that most heterogeneous symptoms of ASD have a common set of events closely connected with dysregulation of glutamatergic neurotransmission in the brain with enhancement of excitatory receptor function by pro-inflammatory immune cytokines as the underlying mechanism. We suggest that environmental and dietary excitotoxins, mercury, fluoride, and aluminum can exacerbate the pathological and clinical problems by worsening excitotoxicity and by microglial priming. In addition, each has effects on cell signaling that can affect neurodevelopment and neuronal function. Our hypothesis opens the door to a number of new treatment modes, including the nutritional factors that naturally reduce excitotoxicity and brain inflammation.
\end{abstract}

Keywords: Autism spectrum disorders, excitotoxicity, fluoride, glutamatergic neurotransmission, inflammation, mercury, microglia, cytokines.

\section{INTRODUCTION}

We have witnessed an alarming increase in the incidence of ASD with rates increasing from 1 in 2,325 births prior to the 1980s to 1 in 101 births today. For male children, the incidence is now 1 in 67 births in some areas of the USA [1]. ASD are a group of related neurodevelopmental disorders, which includes autism, pervasive developmental disordernot-otherwise specified (PDD-NOS), Asperger syndrome, Rett's syndrome, and childhood disintegrative syndrome. The terms ASD and autism are used interchangably. ASD are characterized by a collection of neurobehavioral and neurological dysfunctions, often occurring before age 36 months [2-4]. Despite the great array of observations being made at the cellular and the molecular levels, no one has proposed an integrative and unifying mechanism to explain the heterogenous symptoms and etiology of ASD. Given the major role of glutamate in brain development, some authors have hypothesized that alterations of glutamatergic neurotransmission play a role in the pathophysiology of autism [510]. The hyperglutamatergic hypothesis of autism has been discussed recently $[11,12]$ focusing on findings of increased serum level of glutamate in children and adults with ASD $[13,9]$, the reduction of the levels of rate-limiting enzymes glutamate acid decarboxylase 65 and 67 (GAD65 and GAD67) and the increased gliosis in the brains of autistic subjects $[14,15]$.

A number of studies leave little question that there is a genetic propensity for autism risk. Studies showing higher incidence rates of 60 to $90 \%$ in monozygotic twins versus 0 to $6 \%$ in dizygotic twins suggest a herediability of over $90 \%$ [2]. Data from whole genome screening of multiplex families (having more than one autistic child) strongly suggest that 10 or more genes interact to cause classic autism [16]. Recent

*Address correspondence to this author at the Laboratory of Neuropharmacology, 1st Faculty of Medicine, Charles University in Prague, Albertov 4, 12800 Prague 2, Czech Republic; Tel/Fax: +420 604790 885;

E-mail: strun@natur.cuni.cz research of the autism genome supports further the view that abnormalities in genes connected with glutamate receptors (GluR) and regulation of glutamate pathways may be directly involved in ASD pathology [17]. A significant association between GluR6 gene, located on chromosome 6q21, and autism were found [5, 18, 19]. GluR6 genes control a member of the ionotropic receptor kainate family, which plays a major role in brain development. Strong evidence points to a mutation in chromosome loci $7 \mathrm{q} 31$ in both autism and language disorders [20]. The sequence on chromosome 11p12-13 has been linked to glutamate transport proteins. The neurexin-1 gene (NRXN1) has been shown to play a fundamental role in synaptogenesis and synaptic maintenance, as well as $\mathrm{Ca}^{2+}$ channel and NMDA receptor recruitment [21].

Serajee et al. [22] demonstrated from a study of 196 families having autistic children, a high incidence of mutation of the GRM8 gene controlling the metabotropic GluR8 receptor subunit, which negatively modulates glutamate neurotransmission. Mutation of this gene increases glutamate hyperactivity and thus excitotoxicity. This receptor subunit is located on a number of anatomical areas of the brain affected in autism, including the lateral reticular thalamic nucleus, pyriform cortex and to a lesser degree the cerebellum, caudate and hippocampus [23]. Ramanathan et al. [24] detected abnormalities in genes controlling AMPA receptors (GluR2) as well as glycine receptors (GLRA3 and GLRB), which play a critical role in inotropic GluR control, in a single case of autism. It is obvious from these studies that genetic influence on glutamate function is playing a role in the ASD.

In this paper we offer the explanation of potential etiology of ASD as dysregulation of glutamatergic neurotransmission, with underlying interactions between chronic microglial activation, and the excitotoxic cascade playing the central role. Table 1 gives observed alterations in ASD, which may be connected with dysfunctions of glutamatergic neurotransmission. Moreover, we suggest that the increasing prevalence of ASD during the last decades might reflect the 
Table 1. Observed Alterations in ASD, which may be Connected with Dysfunctions of Glutamatergic Neurotransmission

\begin{tabular}{|c|c|c|}
\hline \multicolumn{2}{|c|}{ OBSERVED ALTERATIONS } & \multirow{2}{*}{\begin{tabular}{|l} 
REFERENCES \\
{$[1,4,25]$}
\end{tabular}} \\
\hline $\begin{array}{l}\text { Neurobehavioral } \\
\text { and neurological }\end{array}$ & $\begin{array}{l}\text { loss of eye contact, deficiencies in socialization, abnormal mind function, language dysfunction, repetitive } \\
\text { behaviors, difficulties with executive prefrontal lobe functions }\end{array}$ & \\
\hline Biochemical & $\begin{array}{l}\text { altered energy metabolism } \\
\text { lower levels of gray matter NAA and Glx } \\
\text { decreased protein levels of GAD } \\
\text { higher concentration of glutamate/glutamine in the amygdala-hippocampal region } \\
\text { increased serum levels of glutamate } \\
\text { increased serum levels of aspartate }\end{array}$ & {$[9,13,32-35]$} \\
\hline Genetic & $\begin{array}{l}\text { GluR6 is abundantly expressed in the hippocampus, basal ganglion and cerebellum, } \\
\text { gene mutation of reelin } \\
\text { deletion of the neurexin } 1 \text { gene } \\
\text { chromosome 11p12-p13 } \\
\text { reduction of GAD67 mRNA in Purkinje cells } \\
\text { mutation of the GRM8 gene } \\
\text { abnormalities in genes for AMPA GluR and glycine receptors }\end{array}$ & $\begin{array}{l}{[5,21,22,24,36-} \\
39]\end{array}$ \\
\hline
\end{tabular}

synergistic action of increased burden of new ecotoxicological factors, which include excitotoxic aminoacids, mainly glutamate and aspartate, fluoride in combination with aluminum $\left(\mathrm{Al}^{3+}\right)$, mercury, and the increasing number of vaccines in the period of rapid postnatal brain development. Our review demonstrates that numerous animal experiments as well as investigations of ASD patients fit well into the immuneglutamatergic hypothesis and opens the door to a number of new treatment modes.

\section{GLUTAMATERGIC NEUROTRANSMISSION IN PHYSIOLOGY AND PATHOPHYSIOLOGY OF THE BRAIN}

\subsection{Regulation of Glutamatergic Neurotransmission}

Glutamate is the principal excitatory neurotransmitter in the brain, acting at more than a half of its synapses. GluR activity is required for fast synaptic transmission as well as for synaptic plasticity, learning and memory, motor coordination, pain transmission, and neurodegeneration. In addition, GluR of various subtypes are to be found on astrocytes, microglia, oligodendrocytes, and neuronal presynaptic sites as well as axons.

The GluR system consists of three ionotropic receptors (NMDA, AMPA, and kainate) and three metabotropic receptors (mGluR) types, with a number of cloned subtypes. The various GluR differ in structure and physiology. Subsequent studies have shown that the GluR system is composed of a very complex set of subunits and receptor types. It is the patterns of subunit assembly within the various GluR that produce the regional differences in the brain's response to glutamate stimulation $[40,41]$. While mGluR belong to the $\mathrm{G}$ protein coupled receptors and mediate changes in intracellular signaling pathways [42, 43], activation of ionotropic GluR AMPA, kainate, and NMDA opens ion channels for sodium ions and $\mathrm{Ca}^{2+}$. Overstimulation of NMDA receptors is one of the mechanisms for $\mathrm{Ca}^{2+}$ overload in neurons and glutamate neurotoxicity $[44,45]$. Also the mGluRs have been implicated in a diverse variety of neuronal functions [46].

Because of the extreme toxicity of extracellular glutamate, even in very small concentrations, there exists a very complex system to prevent extracellular glutamate accumulation. This includes the glutamate reuptake system, which utilizes five excitatory amino acid transporters (EAAT1-5), the first two of which are referred to as glutamate transporter-1 (GLT-1) and glutamate aspartate transporter (GLAST). These sodium and energy-dependent glutamate transporters can move glutamate in either direction, that is, toward astrocyte uptake or into the extracellular space, depending on physiologic and pathologic conditions. Astrocytes, where glutamate is deposited during reuptake, metabolize glutamate to glutamine utilizing the enzyme glutamine synthetase. Consequently, astrocytes are the major regulators of glutamate homeostasis [47]. Dysregulation of the glutamate reuptake system can result in excitotoxicity and abnormal development of the nervous system [48]. Glutamate can also be cleared from the extracellular space by metabolic conversion of glutamate to $\alpha$-ketoglutarate utilizing the enzyme $\alpha$-ketogluterate dehydrogenase and GAD, which converts it to GABA. 
There is an intimate interaction between the mGluR and NMDA receptors, allowing rapid modulation of the excitatory synaptic transmission [49]. The interactions between various types and subtypes of GluR, second messenger molecules, eicosanoid metabolites, reactive oxygen species (ROS), reactive nitrogen species (RNS), lipid peroxidation products (LPP), and phosphorylating enzymes make control of these systems extremely complex. Studies of Martin-Ruiz et al. [50] have disclosed that GluR also interact with serotonergic, adrenergic, and cholinergic neural nets as well.

\subsection{The Excitotoxic Cascade}

Olney [51] discovered the process of excitotoxicity while studying the effect of monosodium glutamate (MSG) on isolated neurons. He found that an excess of extracellular glutamate could trigger a delayed loss of specific neurons. He not only observed destruction of the animals' retinal neurons, but also destruction of selected nuclei in the hypothalamus and other brain structures. He coined the name excitotoxicity, based on the early observation that the neurons seemed to excite themselves to death in a delayed manner.

Excessive activation of the NMDA receptors increase intracellular $\mathrm{Ca}^{2+}$ concentrations, triggering a series of cell signaling systems, which can cause an increase in cellular ROS, RNS, and LPP, and activate the inflammatory prostaglandin (PGE) reactions. By increasing the activity of inducible nitric oxide (NO) synthetase, glutamate increases intracellular NO, which in the presence of increased levels of superoxide can generate high levels of peroxynitrite. Peroxynitrite is very toxic to mitochondria energy-producing enzymes. Reducing cellular energy production has been shown to greatly magnify excitotoxicity [52] to a degree where even physiological levels of glutamate can become excitotoxic.

These processes play a major role in excitotoxic injury and neuronal death. Since the original observation by Olney [51], neuroscientists have discovered that the brain contains abundant GluR and that their excessive stimulation can initiate widespread destruction of a number of brain structures [53]. Several factors, such as the excessive immune activation systemically (inducing a state of chronic brain inflammation), dietary excitotoxins, mercury, fluoride and $\mathrm{Al}^{3+}$ can disrupt the glutamate homeostasis and increase extracellular glutamate levels sufficiently to trigger the excitotoxic cascade.

\subsection{Alterations of Glutamatergic Neurotransmission During Prenatal Development}

Because timed peaks and troughs of glutamate brain levels are important to CNS development [54, 55], factors altering these levels can have devastating effects on brain development and maturation [56]. The timing of the glutamate fluctuations during the developmental profile of the various neural systems allows for a complex array of final neurological events and neurological syndromes. In the developing brain, GluR and glutamate transport proteins have been shown to play a very important role in neuron migration, differentiation and dendritic and synaptic development. For example, the study by Marret et al. [57], using the NMDA receptor agonist ibotenate, found that NMDA excitotoxicity could alter brain architecture and migration patterns in the developing hamster brain involving all levels of radial migratory corridors, including the germinal zone, white matter, cortical plate, and molecular layer. In addition, they found intracortical and molecular layer heterotopias, subcortical and intracortical arrest of migration and ectopias in the molecular layer of the neocortex.

A number of studies have shown that one of the most involved areas of the autistic brain is the cerebellum, particularly involving the Purkinje cells [31, 58, 59]. Of importance is the finding that NMDA receptor activation regulates the migration of granule cells in rat cerebellar slices [60]. Komuro and Rakic [61, 62] demonstrated that oscillations of $\mathrm{Ca}^{2+}$ within the granule cell regulates migration, with peaks producing increased migration and valleys producing an arrest of migration. NMDA, AMPA/kainate, and mGluR, as well as testosterone, modulate $\mathrm{Ca}^{2+}$ oscillations in progenitor neurons and glia, thereby regulating neurodevelopment. Shen and Slaughter [63] found that both glutamate and kainate, acting through NMDA, AMPA, and kainate GluR, respectively, can cause significant elevations in cellular $\mathrm{Ca}^{2+}$ levels without neuron depolarization or excitation that is outright excitotoxicity. Testosterone is also known to enhance glutamate receptor hyperactivity and hence, calcium oscillations. It also suggests a reason for the male preponderance in ASD.

During neurodevelopment, microglial are periodically activated, especially during the most intense periods of synaptic pruning. This activation is a carefully timed process, with a balance between debris removing and neuronal support by an array of growth factors. Microglia in the CNS, much like the macrophages systemically, act as antigen presenting cells. When activated they can release a wide assortment of both proinflammatory and antiinflammatory cytokines, depending of a number of conditions. In addition, microglia contain an array of cytokine receptors on their membrane surface. Beside the cytokines, microglia also secrete a number of cytotoxic molecules, including PGE2, ROS, RNS, LPP, NO, and two excitotoxins-glutamate and quniolinic acid [64, 65]. Dziegielewska et al. [66] demonstrated that cytokines, especially interleukin-1ß (IL-1ß), IL-6, and TNF$\alpha$, play a critical role in brain development and their secretion and ultimate levels are carefully timed and controlled. As a consequence, cytokines appear very early in the neurodevelopmental process.

The immature CNS neurons are exquisitely sensitive to specific disturbances in their synaptic environment. Significant increases in NMDA receptor activity can trigger excitotoxic neurodegeneration. Agents known to alter GluR reactivity include a number of substances that pregnant mothers are exposed to, such as ethanol, phencyclidine, ketamine, barbiturates, benzodiazepines, anti-convulsants or anesthetics. Ethanol, which has NMDA antagonist properties, triggers widespread apoptotic neurodegeneration. Of special concern as well, is the discovery that glutamate, by activating the NMDA receptors on the blood-brain barrier (BBB) can disrupt the barrier, leading to free access of blood-borne toxins to the CNS [67]. In addition, free radicals themselves have been shown to open the BBB [68]. 


\subsection{Dysregulation of Glutamatergic Neurotransmission during Postnatal Development}

Despite significant neuropathological findings and anatomical alterations in classic autism, an increasing number of new cases appearing since the early 1980s, includes a large number who do not show dramatic changes in brain gross anatomy as seen in classic autism. The difference in severity appears to vary with the stage at which the immune/excitotoxic insult arises and its intensity. Postnatal injury is more likely to produce one of the lesser ASD syndromes. In humans, a considerable amount of postnatal brain development occurs, with the greatest period of synaptogenesis and pathway development occurring during the last trimester and the first two years after birth. The timing of the injury during the developmental profile of the various neural systems allows for a complex array of final neurological events and neurological syndromes. An excess of extraneuronal glutamate can interfere with neuron migration patterns, differentiation and synaptic development, resulting in varying degrees of abnormal brain architecture, as we see in the ASD. In the older child, one sees an excessive loss of synaptic connections and pathway maldevelopment.

Elevated glutamate, mercury, fluoride and $\mathrm{Al}^{3+}$ overload, and increased levels of inflammatory cytokines secondary to microglial activation, based on a number of studies, would be expected to affect postnatal brain development. Oxidative damage has been shown to occur in the developing brain and is exacerbated by glutamate excitotoxicity [69].

Carlsson [70] proposed a hypoglutamatergic hypothesis for autism, based on an interaction between overactivity of 5-HT2A serotonin receptors and NMDA GluR. The hypothesis was based on behavioral effects associated with glutamate antagonist and the fact that affected anatomical areas of the brain in autism contain abundant glutamate receptors. The hypothesis does not explain the high incidence of seizures in autistic patients or the finding of elevated glutamate levels in the blood and cerebrospinal fluid (CSF) of autistic children.

Both hyper- and hypoglutamatergic hypothesis are supported by the fact that neuronal migration is interfered with and neuron dropout occurs in both conditions, but the most compelling observations support the excitotoxic hypothesis. For example, most studies have shown an elevation in blood and CSF glutamate levels and widespread microglial and astrocyte activation, both major sites of glutamate release. The pattern of neuronal loss is also consistent with widespread excitotoxic damage.

\subsection{Excitotoxicity and Seizures}

MSG exposure to immature mice and primates leads to a lowering of seizure threshold and a prolongation of seizures [71, 72]. Approximately one-third of autistic children have definable seizures or abnormal EEG seizure foci. Likewise, these abnormal seizure foci [26], with and without clinical seizures, are seen more commonly in autistic children who regress [73]. There is evidence that seizure foci in autistic children have been grossly underdiagnosed. Lewine et al. [29] found epileptiform activity in $82 \%$ of 50 autistic children using the more sensitive magnetoencephalographic technique during stage II sleep.
That excessive glutamate receptor activation plays a major role in seizure-related neurodegeneration is beyond dispute [74]. For example, in the case of pyridoxine-related seizures, neurodegeneration continues unabated despite seizure control if brain glutamate levels remain elevated [75]. One also sees limbic atrophy in the autistic brain. Limbic damage produced by an excitotoxic mechanism is commonly seen with limbic status epilepticus [71].

It is interesting to note that around age two the developing brain contains more synaptic GluR than at birth and the density declines over the next decade, meaning the very immature brain is more susceptible to excitotoxic injury [76]. The increased serum levels of glutamate and aspartate in children and adults with ASD were found with decreased level of glutamine [9, 13, 32,]. Using proton magnetic resonance spectroscopy, Page et al. [35] detected higher concentration of glutamate/glutamine in the amygdala-hippocampal region. While the immature brain is less susceptible to neuron death than the mature brain, seizures in the developing brain result in irreversible changes in neuronal connectivity [77]. Yu et al. [78] found that repeated seizures during early life resulted in persistent changes in the CA1 pyramidal neurons in the hippocampus, which is related to observed behavioral changes.

\section{THE ROLE OF IMMUNE ACTIVATION IN THE ASD PATHOGENESIS}

\subsection{Immune Alterations}

The competency of the immune system is also a major determinative factor. Based on studies of the effects of chronic microglial activation and elevated inflammatory cytokine levels in adults, one would expect similar effects on postnatal brain development $[55,79]$. Abnormalities of immune function are commonly seen in the ASD, most often as immune overactivation or dysregulation [80]. Ashwood with co-workers [81, 82] recently reviewed the immunological abnormalities reported in the ASD, which include abnormal reactivity of lymphocytes, a shift in Th1/Th2 balance, amplified release of TNF- $\alpha$ and IL-1 $1 \beta$ with mononuclear stimulation, presence of various anti-brain antibodies, and specific antibodies to neurotransmitter receptors.

Of special importance to this hypothesis are the immune changes within the brain itself. The most comprehensive and definitive study done to date on the immune alterations in the autistic brain itself was done by Vargas and co-workers [15], in which they examined the brains of 11 autistic patients, 3 years to 45 years of age, dying of non-infectious causes. Control brains were chosen from age-matched individuals dying of similar causes. They performed immunochemistry, cytokine protein arrays, and enzyme-linked immunosorbant assays in the brains and CSF of the patients and controls. Histologically, the greatest amount of damage was seen in the cerebellum, with extensive loss of both Purkinje cells and granule cells. Of particular importance, they observed widespread activation of both microglia and astrocytes throughout the autistic brains, with the greatest activity found in the cerebella, anterior cingulate gyrus and less so in the medial frontal gyrus. 
Analysis of cytokine levels, which examined both proinflammatory and anti-inflammatory cytokines, found a predominance of inflammatory cytokine activity. Most evident was elevations in macrophage chemoattractant protein-1, which plays a role in innate immune reactions, including monocytes, macrophage, and T-cell activation and trafficking into injured zones. IL-6 was significantly elevated in both the brain and CSF of autistics. This cytokine is known to play a vital role in neurodevelopment, yet when chronically elevated, can disrupt brain development and function $[83,84]$. It is important to keep in mind that in the older brains examined in the Vargas et al. study [15], we are still seeing activation of the brain's innate immune system, particularly the microglia, the resident immune cells of the CNS. The source of the chronic immune activation within the brain could include several factors, such as vaccine adjuvants, mercury and $\mathrm{Al}^{3+}$ accumulation within astrocytes and microglia, viral fragments or vaccine derived living viruses (either measles virus or contaminant viruses).

\subsection{The Role of Microglia}

Normally, microglia exist in a resting state, during which time they constitutively express growth factors but no cytokines or excitatory amino acids. A variety of insults, both innate and systemic, can rapidly activate the resting microglia, resulting in their conversion into amoeboid forms that can migrate throughout the brain's extracellular space.

Vallieres et al. [85] and Ekdahl et al. [86] demonstrated considerable evidence that excessive or prolonged microglial activation can disrupt neurogenesis and neurodevelopment, which appears to involve both microglia-induced inflammatory cytokines and excitotoxicity. This is consistent with the findings of Singh et al. [87, 88] of elevated glutamate and inflammatory cytokines in the blood, CSF, and brain of autistic children. Hamberger et al. [89] described four patients with Rett's syndrome who had significantly elevated CSF glutamate levels, thought to originate from microglia. There is also compelling evidence that chronic activation of microglia results in a predominant neurotoxic effect on the brain, with excitotoxic levels of glutamate being secreted $[90,91]$. This means that chronic activation of microglia creates an environment hostile to developing neurons, dendrites and synapses. Inflammatory cytokine membrane receptors interact with GluR in a way that enhances excitotoxicity. It is known that NMDA receptors are co-localized with TNF- $\alpha$ receptors TNFR1 and TNFR2, allowing such crosstalk [92]. TNFR1 is predominantly neurotoxic and TNFR2 is neuroprotective. Neurons contain mostly TNFR1 subtype. The effect of chronic immune cytokine receptor activation on NMDA receptors determines the eventual impact on neurodevelopment, as does the microglial density, which can vary considerably in the brain.

Recently, Takeuchi and co-workers [93] demonstrated that TNF- $\alpha$ increases the release of glutamate from microglia by up-regulating glutaminase, the enzyme responsible for glutamate generation from glutamine. Since systemic immune activation can activate brain microglia, which in turn stimulates microglial-induced release of glutamate, enhancement of glutamate toxicity by this process further endangers neurodevelopment. This is consistent with what we are seeing in the ASD. Laurence and Fatemi [14] quantified levels of glial fibrillary acidic protein (GFAP) and ss-actin in three areas of the brain, namely, area 9, area 40 and cerebellum, in age matched autistic and control postmortem specimens and observed significant elevations in levels of GFAP in all three brain areas in autism. This report confirms microglial and astroglial activation in autism.

The collected data indicates that a number of children with ASD have elevated levels of blood and CSF glutamate and that they have specific immune dysfunction, characterized by chronically elevated levels of brain inflammatory cytokines and chemokines, both of which are known to significantly interfere with neurodevelopment. Further, we have shown that inflammatory cytokines magnify the neurotoxic effects of glutamate significantly. For example, Qiu et al. [94] found that under physiological conditions IL-6 levels were very low, but with microglial activation IL-6 levels rise substantially. Further, they found that higher levels of IL-6 enhanced the sensitivity of the NMDA receptors in developing cerebellar granule cell neurons, resulting in a significant membrane depolarization and increased intracellular calcium levels. Neurotoxicity to the neurons was significantly elevated in granules cell neurons exposed to the higher levels of IL-6.

The question remains - what is causing the chronic immune activation of the brain? We believe that there is compelling evidence that excessive systemic immune stimulation through a combination of numerous and closely spaced vaccinations, immune and excitotoxic effects of the mercury additive thimerosal, systemic infections, food allergies, Candida infections, and genetic factors all play a part. Activation of microglia is strongly linked to IL-1B, which can enter the CNS following systemic immune activation, thus providing a link between vaccination and the brain inflammations [15] even though other sources of systemic immune activation may play a role.

\subsection{Systemic Immune Activation and Microglial Priming}

Activation of brain microglia by systemic immune stimulation can occur by way of macrophage/lymphocyte interactions at the choroid plexus and BBB interface, by IL- $1 \beta$ infiltration into the brain and via the vagal and trigeminal afferents [95]. IL-1 $\beta$ has been shown to interact with amygdalar neuron receptors, indicating an important interaction with the systemic immune system [96]. Amygdalar involvement is considered to play an important role in the ASD. Likewise, Kim et al. [97] found that systemic injections of lipopolysacharide (LPS) resemble the immune effects of vaccinations. Another important observation is the effect of immune priming on the brain immune/excitotoxic process described above. Preexisting microglial activation has been shown to greatly magnify neurodegeneration associated with subsequent episodes of systemic immune activation; a process called microglial priming [95, 98]. For example, Cunningham et al. [99] found that priming brain microglia with an antigen (ME7) followed by systemic LPS challenge produced a 3 -fold higher increase in brain IL-1 $1 \beta$ than when microglia was not primed. Since IL- $1 B$ is the primary activator of microglia, this would explain a similar effect 
with repeated vaccination in autistic children, with the first inoculation priming the microglia.

Recently, for the first time, this phenomenon has been demonstrated in humans. Lemstra and co-workers [100] selected a series of autopsied humans having systemic infections but no signs of CNS involvement and demonstrated intense, diffuse microglial activation in their brains using CD68 immunostaining. Matched controls demonstrated only age-related microglial activation that was significantly less intense. Likewise, it has been observed that autistic children often suffer from repeated systemic infections, usually of the middle ear, which would also act to prime the microglia. In this case, subsequent vaccinations would produce an exaggerated immune response within the still developing brain. Another possibility would be the use of live viruses in vaccines, especially with studies showing measles viruses residing within the brain throughout life [101]. The live virus, or even viral particles could act as priming antigens for microglia. Other vaccine-related antigenic substances could also result in priming.

For example, mercury and $\mathrm{Al}^{3+}$ can produce a priming effect, since both metals activate microglia. Charleston et al. [102] found that exposing monkeys (Macaca fascicularis) chronically to oral methylmercury $(\mathrm{MeHg})$ resulted in extensive microglial and astrocyte activation, which persisted six months after dosing ceased. Vahter et al. [103] demonstrated that it was the ionic form of mercury (demethylated $\mathrm{MeHg}$ ) that was most toxic and that it gradually accumulated in the brain over an 18 month period. Of special importance when comparing ethylmercury ( $\mathrm{EtHg}$ ) with $\mathrm{MeHg}$ brain toxicity, is that even though EtHg brain levels were 3-fold lower than $\mathrm{MeHg}, 34 \%$ of the EtHg was converted to the more toxic ionic form of mercury and only $7 \%$ of $\mathrm{MeHg}$ was converted in a similar time frame $[104,105]$.

Wakefield et al. [28] provided compelling evidence that the gastrointestinal tract of autistic children is incompetent, resulting in the leaky gut syndrome. This allows food antigens to enter the blood stream, resulting in a high incidence of food allergy, especially to gliadin and gluten [81]. In addition, a number of studies have shown a cross reaction between food antigens and neuron-specific antigens. For example, studies of Vojdani et al. [106, 107] found food antigens in 50 autistic children that cross-reacted specifically with Purkinje neurons. Another initiator of microglial priming could be Candida infections [108, 109] or other colon bacterial diseases, which are also reported to be common in children with ASD.

\section{ENVIRONMENTAL EXCITOTOXINS OF CON- CERN IN CHILDREN WITH ASD}

\subsection{Effect of Dietary Food Additive Excitotoxins}

Also of concern is the observation that autistic children tend to prefer junk type foods, most of which contain significant amounts of excitotoxic additives as well as $\mathrm{Al}^{3+}$ and fluoride. Orally ingested MSG has been shown to raise blood glutamate levels as much as 20 to 45 -fold higher than baseline values $[110,111]$. It has also been shown, using radiolabeled $\left[{ }^{3} \mathrm{H}\right]$-glutamate, that MSG can pass through the placenta and preferentially accumulate in the fetal brain [78]. Likewise, Olney et al. [112] have shown that the immature brain is approximately 4-times more sensitive to glutamate excitotoxicity as the adult brain. An explanation for hypersensitivity of the immature brain lies in the observation that during brain development the NMDA receptor is more sensitive to glutamate and less responsive to magnesium protection.

Frieder and Grimm [113, 114] have demonstrated that feeding MSG to pregnant rats can lead to severe alterations in learning that only affected the male rats, again demonstrating a male preponderance of toxic effects. It has also been shown that sensitivity to glutamate increases after birth $[115,116]$. A number of studies have also demonstrated that MSG feeding early in life can lead to prolonged free radical generation in the brain, which can last until adult stages of life $[117,118]$. Of great concern is the finding of MartinezContreras et al. [119] that glutamate can prime microglia, leading to brain inflammation and high levels of inflammatory cytokines in the brain. In addition, some studies [114, 120] have demonstrated alteration in hippocampal architecture and synaptic development following neonatal exposure to MSG in animal models.

Behavioral studies have also shown that exposure to excess glutamate during critical periods of brain development can produce prolonged alterations in behavior [121, 122]. The treatment with glutamate during the early postnatal period in rats resulted in defects in adjusting to a new environment 21 and 60 days later, something commonly found in ASD [123]. The behavioral effects are more common in male animals, with few effects being found in the females. Affected males showed little social interest in their littermates, demonstrated defects in novelty and perceptual mechanisms and an inability to focus attention, again all characteristics of the child with one of the ASD disorders.

Several studies indicate that exaggerated signaling through mGluR5 can account for multiple cognitive and syndromic features of fragile $\mathrm{X}$ syndrome, the most common inherited form of mental retardation and autism [46]. In humans, fragile $\mathrm{X}$ syndrome is associated with an increase incidence of autistic behavior, anxiety disorders, epilepsy, sensory processing disorders, and delays in speech and language function. Alterations in mGluR group I signaling were identified in a fragile X mouse model. Yan et al. [124] studied the effect of mGluR5 antagonists on audiogenic seizures and open field activity of the fragile $\mathrm{X}$ mental retardation 1 gene (FMR1- tm1Cgr) mice. They found that mGluR5 antagonists were able to rescue two of the major phenotypes of the FX mouse and concluded that modulation of mGluR5 signaling may allow amelioration of symptoms of fragile $\mathrm{X}$ syndrome. Wilson and Cox [125] also reported decreased activity of mGluR in mice with fragile $\mathrm{X}$ syndrome, which can affect synaptic plasticity and increase activity of NMDA receptors. A recent study demonstrated that Drosophila melanogaster having a deletion of the FMR1 developed many of the phenotypes of the fragile $\mathrm{X}$ syndrome and that insects reared on foods high in glutamate show lethal excess sensitivity in glutamate signaling [126].

\subsection{The Role of Mercury}

A number of studies have proposed a connection between mercury exposure, especially through thimerosal-containing 
vaccines, and the rising incidence of autism [127, 128]. Architectonic abnormalities are known to occur with mercury exposure during fetal development, which can result in abnormalities in neuronal and glial proliferation and neuronal migration $[129,130,104]$. Especially affected is the cerebellum.

The mechanism by which mercury produces these effects may include critical enzyme inhibition, ROS and LPP generation, and excitotoxicity. Critical to mercury's toxicity on the developing, as well as adult brain, is the excitotoxic process, since blocking NMDA receptors significantly attenuates mercury toxicity $[131,132]$. One of the essential components of the excitotoxic process is generation of ROS, RNS, and LPP. Free radicals have been shown to dramatically increase the sensitivity to both mercury toxicity and excitotoxicity $[133,134]$. One of the more destructive free radicals is peroxynitrite, which is generated through a combination of superoxide and NO, both of which are generated in excess with excitotoxicity. Significant elevations in measures of oxidative stress and LPP in autistic children were demonstrated $[135,136]$.

New evidence points to a strong connection between brain inflammation, mitochondrial failure, and excitotoxicity, all of which involve GluR-induced intraneuronal $\mathrm{Ca}^{2+}$ accumulation [137]. Mercury, by inducing GluR activation, greatly magnifies this process. Hornig and co-workers [138] found that the neurotoxic effects of thimerosal were mouse strain dependent, with mice having genetic autoimmune sensitivity showing reduce locomotion, growth delay, exaggerated response to novelty, densely packed, hyperchromatic hippocampal neurons, and altered glutamate receptors and transporters.

Another way mercury triggers excitotoxicity is by inhibiting glutamate transport. A number of studies have shown that glutamate transporters are quite sensitive to mercury toxicity, with concentrations as low as $0.5 \mu \mathrm{M}$ producing a $50 \%$ suppression of glutamate uptake by astrocytes in culture [139]. It has also been shown that GLAST and EAAT4 are essential for protection of Purkinje cells against excitotoxicity [140]. This could explain the dramatic loss of Purkinje cells. The ability of mercury to induce glutamate accumulation in the brain has also been demonstrated [141]. In this study, they instilled $\mathrm{MeHg}$ into the frontal cortex of awake, freely moving rats. At a dose of $10 \mu \mathrm{M}$ they found a 9.8 -fold rise in extracellular glutamate and at $100 \mu \mathrm{M}$ dose they observed a 2.4-fold rise, indicating that a lower dose of mercury was significantly more excitotoxic.

The most efficient mercury detoxification systems in the brain include glutathione and metallothionein, both of which bind numerous atoms of mercury. Glutathione, in addition, is one of the cell's most efficient antioxidant systems. The neuron's sole source of glutathione is the astrocyte. With mercury preferentially accumulating within the astrocyte, a greater percentage of glutathione molecules will be inactivated under conditions of mercury loading. Ou et al. [142] and Shanker et al. [143] shown that mercury reduced glutathione levels in immature and adult neurons.

\subsection{The Role of Aluminum and Fluoride}

Other than as an adjuvant in many vaccines, $\mathrm{Al}^{3+}$ is also found in a number of baked goods, including pancakes, biscuits, processed cheeses, and teas. The study by Yokel and Florence [144] concluded that foods supplied 25 times more $\mathrm{Al}^{3+}$ than did drinking water. In addition, new studies have found very high levels of $\mathrm{Al}^{3+}$ in a number of common parental and intravenous feeding solutions used in pediatrics [145]. $\mathrm{Al}^{3+}$ not only accumulates in the brain, but has been shown to produce inflammation via microglial activation, elevated levels of ROS and LPP $[146,147] . \mathrm{Al}^{3+}$ has also been shown to enhance excitotoxicity [148].

Fluoride exposure is also common in fetuses, newborns, and small children as a result of the artificial fluoridation of drinking water and a dramatic increase in the volume of man-made industrial fluoride compounds released into the environment. Mullenix et al. [149] demonstrated significant behavioral changes in rats exposed neonatally to fluoride in drinking water, with the effects dependent on the timing of the dose, concentration, and sex of the animals. They found males were more affected with prenatal exposure and females if the exposure occurred after weaning or adulthood.

Fluoride also interferes with a number of glycolytic enzymes, resulting in a significant suppression of cellular energy production. New studies have found that many of the effects primarily attributed to fluoride are instead caused by a synergistic action of fluoride plus $\mathrm{Al}^{3+}$ that is, with the aluminofluoride complex (AlFx) acting as analogue of phosphate group and general activator of $G$ proteins [150]. The activation of $\mathrm{G}$ protein by AlFx may evoke cascades of biochemical reactions and numerous alterations in the brain with various pathological consequences [151]. Fluoride could complex with any pre-existing $\mathrm{Al}^{3+}$ within body fluids to produce the AlFx and this could lead to a combination of chronic activation of $\mathrm{G}$ protein regulated systems, increased intracellular level of $\mathrm{Ca}^{2+}$, and sustained activation of receptor functions. A number of studies have shown that AlFx can affect learning and behavior, and induce a loss of cerebrovascular integrity in experimental animals. With the accumulation of AlFx within the developing brain one would also expect microglial reaction, if for no other reason, from the high level of ROS and LPP. This could be another significant source of priming of microglia as well as excitotoxicity [7].

Some symptoms of ASD such as the sleep problems and the early onset of puberty suggest abnormalities in melatonin physiology and dysfunctions of the pineal gland. Luke [152] reported that fluoride accumulates in the pineal gland and that mongolian gerbils fed higher doses of fluoride excreted less melatonin metabolite in their urine and took a shorter time to reach puberty. Many studies indicate clearly that nocturnal production of melatonin is reduced in ASD [153]. Melatonin is responsible for regulating numerous life processes, including development and aging [154]. It is also known that production of melatonin by the pineal is controlled by GluR and that excess aspartate or glutamate activity can inhibit melatonin release. Melatonin has been shown to have powerful neutralizing effects on ROS and LPP and to 
increase the levels of several of the antioxidant enzymes in the brain. A study of Tauman et al. [155] revealed that babies with the lowest melatonin production had the most neurobehavioral problems.

\section{PREVENTION AND AMELIORATION OF ASD}

Despite the intensive research of pharmacotherapy of ASD, drugs with consistent effects have not yet been developed. It is believed, that exploration of therapeutic strategies affecting glutamatergic and neuroimmune function may provide new insights into the treatment of $\operatorname{ASD}[156,8,46]$. The double-blind, placebo-controlled, parallel group study of lamotrigine, an agent that modulates glutamate release from neurons, which involved 28 children (27 boys) ages 3 to 11 years with a primary diagnosis of ASD, did not find any significant differences in improvements of symptoms [157]. Unfortunately, this drug reduces the synaptic release of glutamate from neurons, whereas in ASD the source of the glutamate is the microglia and astrocytes and/or the endogenous glutamate. As previously cited, elevations in CSF and blood glutamate levels are commonly found in ASD.

Chronic maintenance therapy with memantine - a moderate affinity antagonist of the NMDA GluR - showed significant improvements in open-label use for language function, social behavior, and self-stimulatory behaviors in patients with autism and PDD-NOS [158, 10], supporting the hypothesis about the role of dysregulation of glutamatergic neurotransmission. Open-label add-on therapy was offered to 151 patients over a 21-month period. Chronic use so far appears to have no serious side effects [10]. Erickson et al. [158] studied eighteen children and adolescents with PDD over a mean duration of 19.3 weeks (range 1.5-56 weeks). Eleven of $18(61 \%)$ patients were judged responders to memantine based on a rating of "much improved" or "very much improved". Controlled studies are warranted to further assess the efficacy and safety of memantine in PDD.

Since a reduction of mGluR5 signaling can reverse fragile X phenotypes, the recent review of Dölen and Bear [46] provides a compelling rationale for the use of mGluR5 antagonists for the treatment of autism.

It is reasonable to conclude that autistic children are exposed to a number of environmental and food-based excitotoxin additives that can worsen brain inflammation and excitotoxicity resulting in dysregulation of glutamate homeostasis and do so for a prolonged time. The competency of the CNS protective mechanisms, especially the antioxidant systems, determines, to a large extent, the final outcome [159]. Early nutrition has been shown to play a major role in the brain development, mental and immune function. Children and adolescents with poor nutritional status are exposed to alterations of mental and behavioral functions that can be corrected to a certain extent by dietary measures [160]. Moreover, feeding dysfunctions, such as vitamins or carnitine deficiency, have been reported as an integral part of ASD [161, 162].

Many of the diets now being proposed for autistic children emphasize elimination of foods known to be exceedingly high in excitotoxin additives, even though they are being eliminated for other reasons. They are also low in sugar. Autistic children have altered energy metabolism [33] and a high incidence of reactive hypoglycemia, which increases their risk of seizures and excitotoxicity. The mechanism for this amplification is not known specifically. It may occur as a result of enhancement of free radicals and lipid peroxidation products. It is a well accepted phenomenon. Jones et al. [163] demonstrated that children respond to glucose challenges with a hypoglycemic response at higher levels of blood glucose than adults.

Many of the vitamins used to treat ASD are antioxidants, which can significantly reduce excitotoxicity. A preliminary trial exploring the effectiveness of ascorbic acid $(8 \mathrm{~g} / 70 \mathrm{~kg} /$ day) as a supplemental pharmacological treatment for autistic children reported a reduction in symptom severity [164]. Experimentally, vitamin E, thiamine, riboflavin, pyridoxine, methylcobalamin, folate, and nicotinamide have been shown to significantly reduce glutamate toxicity in vitro [165]. Vitamin B6 can dramatically lower blood and tissue glutamate levels and raises seizure thresholds. In addition, along with folate and vitamin B12, it reduces homocysteine levels. Methylcobalamin is a GluR blocker [166] and supplementation improves cerebral and cognitive functions [160]. Pyridoxine's ability to powerfully inhibit excitotoxity at least partially explains the sometimes dramatic results in treating autistic children with high dose pyridoxine/magnesium combinations [167].

There is growing evidence that the neurohormone, vitamin D3, plays a major role in brain homeostasis. Recent studies have shown that the human brain has a very similar distribution of vitamin $\mathrm{D}$ receptors (VDR) as the mouse and rat brain, with higher concentrations of the receptor in the cerebellum, hippocampus, limbic system, pituitary, substantia nigra, white matter, diencephalon and cerebral cortex [168]. The hippocampus contains high levels of VDR in $\mathrm{CA} 1, \mathrm{CA} 3$ and CA4, with particularly intense staining in CA2. A variable pattern of VDR staining was seen in the amygdala. Taniura et al. [169] demonstrated very high activity for vitamin D specific DNA-response element (VDRE) binding in the cerebellum, an area of the brain most severely affected in autism. They suggest a trophic role for vitamin D3 in the CNS and also noted that the neurohormone significantly protected cultured cortical neurons from glutamate excitotoxicity. Protection from excitotoxicity appeared to be from upregulation of the VDR.

Cannell [170] suggested that vitamin D deficiency may play a central role in ASD based on studies showing that vitamin D3 deficiency during embryogenesis resulted in an enlarged head, excess neurogenesis, enlarged ventricles and the cortex was thinner. Several studies have shown that a larger proportion of ASD children have an enlarged head circumference and macroencephaly [171].

Interestingly, it is known that microglia not only contain VDR but also can manufacture 1,25 dihydroxyvitamin D3 when activated [172, 173]. Studies have also shown that during activation the number of VDR are up-regulated within the microglia. Importantly, vitamin D3 has been shown to decrease microglial activation [174]. A significant number of studies have shown that high levels of vitamin D3 can significantly reduce the incidence and pathology of a number of autoimmune diseases, including experimental 
allergic encephalomyelitis (EAE) [175]. When given after EAE was induced, the vitamin D3 arrested further progression of the pathology.

Several studies have shown that vitamin D3 induces an increased production of anti-inflammatory cytokines such as IL-10, IL-4 and TGF- $ß 1$ [176]. A deficiency produces a proinflammatory cytokine profile. Vitamin D3 has also been shown to suppress NOS and elevate glutathione levels. In addition, vitamin D3 dramatically stimulates glial derived neurotropic factor (GDNF) production, which is neuroprotective [177].

Magnesium and zinc also powerfully inhibit excitotoxicity as well as act as co-factors in numerous enzyme systems. Low magnesium is associated with dramatic increases in free radical generation as well as glutathione depletion. In addition, low magnesium enhances NMDA sensitivity, making excitotoxicity more likely, even in the presence of physiological levels of extracellular glutamate. High glutamate levels have also been shown to deplete cellular glutathione. Glutathione is vital since it is one of the few antioxidant molecules known to neutralize 4-hydroxynonenal and mercury, both of which interfere with glutamate uptake. Of great interest is the use of selected flavonoids as antioxidants, antiinflammatories, GluR blockers, and antimicrobials. The flavonoids are more powerful and versatile as antioxidants than are the vitamins [178]. Likewise, a number of nutraceutical compounds and pharmaceuticals have been shown to reduce microglial activation. The special nutrients that have been shown to reduce excitotoxicity and microglial activation are given in Table $\mathbf{2}$.

The long-term fluoride burden has several health effects with a striking resemblance to the ASD. These include hypocalcemia, hypomagnesemia, hypothyroidism, sleeppattern disturbance, and IQ deficits [151]. Conceivably, fluoride inhibits release of pineal melatonin by elevating glutamate levels. A randomized, placebo-controlled doubleblind crossover trial of melatonin taken by 11 children with ASD provided evidence of effectiveness of melatonin in children with sleep difficulties [179].

\section{CONCLUSION}

The advanced knowledge of polygenetic and heterogenetic nature of ASD makes an elucidation of the genetic basis of autism extremely challenging. Recent research has focused on the role of synapse structure and signaling pathways in the brain as central to the development of ASD. Anderson [180] suggests in his review that the novel, "emergent" phenomena may arise in the individual from interacting of underlying genetic and biological factors or cooccurring traits.

Our review presents evidence suggesting that the clinical as well as pathological findings of the ASD have a common set of events, with the common denominator being the dysfunctional glutamatergic neurotransmission and chronic microglial activation. We also know that a number of factors can trigger both the inflammatory cascade and the excitotoxic cascade, including hypoxia/ischemia, hypoglycemia, hypomagnesmia, ROS, RNS and LPP, fluoride, $\mathrm{Al}^{3+}$, and mercury. Further, chronic activation of the brain's immune system increases extracellular glutamate levels sufficiently to trigger the excitotoxic cascade, which in conjunction with inflammatory cytokines and PGE2, magnifies the damaging effects of both. This mechanism explains most of the features of the ASD, including the behavioral difficulties, language problems, repetitive behaviors, intellectual delay, and episodic dyscontrol of anger. In addition, these mechanisms explain the pathological findings as well, including the changes in the cerebellum, neuronal migration abnormalities in the amygdala and other limbic structures, abnormal pathway development, and the widespread activation of microglia and astrocytes. It also explains why ASD has not disappeared despite the reduction in mercury exposure from most childhood vaccines, since excessive immune activation is the initiating and sustaining event in ASD. It is to be appreciated that mercury, even in submicromolar concentrations, can initiate excitotoxicity. The vaccination program should be evaluated to reduce the excessive stimulation of the immature immune system. We have also reviewed studies that indicate that dietary excitotoxins, fluoride, and $\mathrm{Al}^{3+}$ can exacerbate the pathological and clinical problems by worsen-

Table 2. Prevention and Amelioration of ASD

\begin{tabular}{|c|c|}
\hline \multicolumn{2}{|c|}{ SPECIAL SUPPLEMENTS AND COMPOUNDS, WHICH ARE KNOWN TO REDUCE } \\
\hline EXCITOTOXICITY & MICROGLIAL ACTIVATION \\
\hline \hline Methylcobalamin (vitamin B12) & Ibupropen \\
\hline Pyridoxal-5 phosphate (vitamin B6) & Mincycline \\
\hline Vitamin E (mixed tocopherols) & Ferulic acid \\
\hline Vitamin C (buffered) & DHEA \\
\hline CoQ10 & Quercumin \\
\hline Acetyl-L-carnitine & Silymarin \\
\hline Alpha-lipoic acid & Baicalein \\
\hline Magnesium glycinate or lactate & Resveratrol \\
\hline Zinc & DHA/EPA \\
\hline Flavonoids & \\
\hline
\end{tabular}


ing excitotoxicity, immune activation, and microglial priming.

Moreover, most of the excitotoxic factors may enhance the subclinical pathological alterations and/or the genetic susceptibility. The significant physiological implication brought the observations of additive effects of low excitotoxin concentrations with an ineffective hormonal agonist resulting in a maximally effective response [151]. The principle of amplification of the initial signal during its conversion into functional response has been a widely accepted tenet in cell physiology. Such mechanism could explain the emergence phenomena on the molecular and cell level. The full genetic potential of the child for brain and mental development may be also compromised due to deficiency of micronutrients.

Our immune-glutamatergic hypothesis opens the door to a number of new modes of prevention and amelioration of these increasingly prevalent disorders. As a multifaceted disorder, ASD requires a multifaceted approach, one that should include the protection against excitotoxicity/microglial activation, such as the prevention of long-term fluoride and $\mathrm{Al}^{3+}$ burden, the reduction of processed food in diets with glutamate and aspartate-containing additives, and nutrition with special nutrients that have been shown to reduce excitotoxicity and microglial activation.

\section{ACKNOWLEDGEMENT}

The financial support of the Grant MSM 0021620806 of the Czech Republic is highly appreciated.

\section{ABBREVIATIONS}

$\begin{array}{ll}\text { AlFx } & =\text { Aluminofluoride complexes } \\ \text { AMPA } & =\alpha \text {-amino-3-hydroxy-5-methyl-4-isoxazole } \\ \text { ASD } & =\text { Autiopionic acid } \\ \text { BBB } & =\text { Blood- brain barrier } \\ \text { CNS } & =\text { Central nervous system } \\ \text { CSF } & =\text { Cerebrospinal fluid } \\ \text { EAAT } & =\text { Excitatory amino acid transporters } \\ \text { EAE } & =\text { Experimental allergic encephalomyelitis } \\ \text { EtHg } & =\text { Ethylmercury } \\ \text { GABA } & =\gamma \text {-amino butyric acid } \\ \text { GAD } & =\text { Glutamate acid decarboxylase } \\ \text { GFAP } & =\text { Glial fibrillary acidic protein } \\ \text { GLAST } & =\text { Glutamate aspartate transporter } \\ \text { GLT-1 } & =\text { Glutamate transporter-1 } \\ \text { GluR } & =\text { Glutamate receptors } \\ \text { IL } & =\text { Interleukins } \\ \text { LPP } & =\text { Lipid peroxidation products } \\ \text { LPS } & =\text { Lipopolysacharide }\end{array}$

$\begin{array}{ll}\text { MeHg } & =\text { Methylmercury } \\ \text { mGluR } & =\text { Metabotropic glutamate receptors } \\ \text { MSG } & =\text { Monosodium glutamate } \\ \text { NMDA } & =N \text {-methyl-D-aspartic acid } \\ \text { NO } & =\text { Nitric oxide } \\ \text { PDD-NOS } & =\text { Pervasive developmental disorder-not- } \\ \text { PGE } & =\text { Prostaglandins } \\ \text { RNS } & =\text { Reactive nitrogen species } \\ \text { ROS } & =\text { Reactive oxygen species } \\ \text { TNF- } \alpha & =\text { Tumor necrosis factor- } \alpha \\ \text { TNFR } & =\text { Tumor necrosis factor- } \alpha \text { receptor } \\ \text { VDR } & =\text { Vitamin D receptors }\end{array}$

\section{REFERENCES}

[1] Rice, C.E. Prevalence of autism spectrum disorders - autism and developmental disabilities monitoring network. Six sites, United States, 2000. MMWR Surveillance Summaries, 2007, 56, 1-11.

[2] Bailey, A.; Le Couteur, A.; Gottesman, I.; Bolton, P.; Simonoff, E.; Yuzda, E.; Rutter, M. Autism as a strongly genetic disorder: evidence from a British twin study. Psychol. Med., 1995, 25, 63-77.

[3] Bethea, T.C.; Sikich L. Early pharmacological treatment of autism: a rationale for developmental treatment. Biol. Psychiatry, 2007, 61, 521-37.

[4] Greenspan, S.I; Brazelton, T.B.; Cordero, J.; Solomon, R.; Bauman, M.L.; Robinson, R.; Shanker, S.; Breinbauer, C. Guidelines for early identification, screening, and clinical management of children with autism spectrum disorders. Pediatrics, 2008, 121, 82830 .

[5] Purcell, A.E.; Jeon, O.H.; Zimmerman, A.W.; Blue, M.E.; Pevsner, J. Postmortem brain abnormalities of the glutamate neurotransmitter system in autism. Neurology, 2001, 57, 1618-28.

[6] Blaylock, R.L. The central role of excitotoxicity in autism spectrum disorders. JAMA, 2003, 6, 10-22.

[7] Blaylock, R.L. Excitotoxicity, a possible central mechanism in fluoride neurotoxicity. Fluoride, 2004, 37, 264-77.

[8] McDougle, C.J.; Erickson, C.A.; Stigler, K.A.; Posey, D.J. Neurochemistry in the pathophysiology of autism. J. Clin. Psychiatry, 2005, 66, Suppl 10, 9-18.

[9] Shinohe, A.; Hashimoto, K.; Nakamura, K.; Tsujii, M.; Iwata, Y.; Tsuchiya, K.J.; Sekine, Y.; Suda, S.; Suzuki, K.; Sugihara, G.; Matsuzaki, H.; Minabe, Y.; Sugiyama, T.; Kawai, M.; Iyo, M.; Takei, N.; Mori, N. Increased serum levels of glutamate in adult patients with autism. Prog. Neuropsychopharmacol. Biol. Psychiatry, 2006, 30, 1472-77.

[10] Chez, M.G.; Burton, Q.; Dowling, T.; Chang, M.; Khanna, P.; Kramer, C. Memantine as adjunctive therapy in children diagnosed with autistic spectrum disorders: an observation of initial clinical response and maintenance tolerability. J. Child Neurol., 2007, 22, 574-79.

[11] Hashimoto, K.; Shinohe, A.; Mori, N. Reply to: The hyperglutamatergic hypothesis of autism. Prog. Neuropsychopharmacol. Biol. Psychiatry, 2007, Nov 13, (ahead of print).

[12] Fatemi, S.H. The hyperglutamatergic hypothesis of autism. Prog Neuropsychopharmacol. Biol. Psychiatry, 2008, 32, 911.

[13] Aldred, S.; Moore, K.M.; Fitzgerald, M.; Waring, R.H. Plasma amino acid levels in children with autism and their families. $J$. Autism Dev. Disord., 2003, 33, 93-7.

[14] Laurence, J.A.; Fatemi, S.H. Glial fibrillary acidic protein is elevated in superior frontal, parietal and cerebellar cortices of autistic subjects. Cerebellum, 2005, 4, 206-10.

[15] Vargas, D.L.; Nascimbene, C.; Krishnan, C.; Zimmerman, A.W.; Pardo, C.A. Neuroglial activation and neuroinflammation in the brain of patients with autism. Ann. Neurol., 2005, 57, 67-81. 
[16] Risch, N.; Spiker, D.; Lotspeich, L.; Nouri, N.; Hinds, D.; Hallmayer, J.; Kalaydjieva, L.; McCague, P.; Dimiceli, S.; Pitts, T.; Nguyen, L.; Yang, J.; Harper, C.; Thorpe, D.; Vermeer, S.; Young, H.; Hebert, J.; Lin, A.; Ferguson, J.; Chiotti, C.; Wiese-Slater, S.; Rogers, T.; Salmon, B.; Nicholas, P.; Petersen, P. B.; Pingree, C.; McMahon, W.; Wong, D. L.; Cavalli-Sforza, L. L.; Kraemer, H. C.; Myers, R. M. A genomic screen of autism: evidence for a multilocus etiology. Am. J. Hum. Genet., 1999, 65, 493-507.

[17] Gupta, A.R.; State, M.W. Recent advances in the genetics of autism. Biol. Psychiatry, 2007, 61, 429-37.

[18] Philippe, A.; Martinez, M.; Guilloud-Bataille, M.; Gillberg, C.; Rastam, M.; Sponheim, E.; Coleman, M.; Zappella, M.; Aschauer, H.; Van Maldergem, L.; Penet, C.; Feingold, J.; Brice, A.; Leboyer, M. Genome-wide scan for autism susceptibility genes. Paris Autism Research International Sibpair Study. Hum. Mol. Genet., 1999, 8, 805-12.

[19] Jamain, S.; Betancur, C.; Quach, H.; Philippe, A.; Fellous, M.; Giros, B.; Gillberg, C.; Leboyer, M.; Bourgeron, T. Linkage and association of the glutamate receptor 6 gene with autism. Mol. Psychiatry, 2002, 7, 302-10.

[20] IMGSAC. Further characterization of the autism susceptibility locus AUTS1 on chromosome 7q. Hum. Mol.Genet., 2001, 10, 97382.

[21] Autism Research Consortium. Mapping autism risk loci using genetic linkage and chromosomal rearrangements. Nat. Genet., 2007, 3, 319-28.

[22] Serajee, F.J.; Zhong, H.; Nabi, R.; Huq, A.H. The metabotropic glutamate receptor 8 gene at 7q31: partial duplication and possible association with autism. J. Med. Genet., 2003, 40, e42.

[23] Malherbe, P.; Kratzeisen, C.; Lundstrom, K.; Richards, J.G.; Faull, R.L.; Mutel, V. Cloning and functional expression of alternative spliced variants of the human metabotropic glutamate receptor 8 . Brain Res. Mol. Brain Res., 1999, 67, 201-10.

[24] Ramanathan, S.; Woodroffe, A.; Flodman, P. L.; Mays, L. Z.; Hanouni, M.; Modahl, C. B.; Steinberg-Epstein, R.; Bocian, M. E.; Spence, M. A.; Smith, M. A case of autism with an interstitial deletion on $4 \mathrm{q}$ leading to hemizygosity for genes encoding for glutamine and glycine neurotransmitter receptor sub-units (AMPA 2, GLRA3, GLRB) and neuropeptide receptors NPY1R, NPY5R. BMC Med. Genet., 2004, 5, 10.

[25] Gamliel, I.; Yirmiya, N.; Sigman, M. The development of young siblings of children with autism from 4 to 54 months. J. Autism Dev. Disord., 2007, 37, 171-83.

[26] Rapin, I. Autistic regression and disintegrative disorder: how important the role of epilepsy? Semin. Pediatr. Neurol., 1995, 2, 278-85.

[27] Tordjman, S.; Anderson, G.M.; McBride, P.A.; Hertzig, M.E.; Snow, M.E.; Hall, L.M.; Ferrari, P.; Cohen, D.J. Plasma androgens in autism. J. Autism Dev. Disord., 1995, 25, 295-304.

[28] Wakefield, A. J.; Murch, S. H.; Anthony, A.; Linnell, J.; Casson, D. M.; Malik, M.; Berelowitz, M.; Dhillon, A. P.; Thomson, M. A.; Harvey, P.; Valentine, A.; Davies, S. E.; Walker-Smith, J. A. Ileallymphoid-nodular hyperplasia, non-specific colitis, and pervasive developmental disorder in children. Lancet, 1998, 351, 637-41.

[29] Lewine, J. D.; Andrews, R.; Chez, M.; Patil, A. A.; Devinsky, O.; Smith, M.; Kanner, A.; Davis, J. T.; Funke, M.; Jones, G.; Chong, B.; Provencal, S.; Weisend, M.; Lee, R. R.; Orrison, W. W., Jr. Magnetoencephalographic patterns of epileptiform activity in children with regressive autism spectrum disorders. Pediatrics, 1999, 104, 405-18.

[30] Blaylock, R.L. Interaction of cytokines, excitotoxins, and reactive nitrogen and oxygen species in autism spectrum disorders. JAMA, 2003, 6, 21-35.

[31] Palmen, S.J.; van Engeland, H.; Hof, P.R.; Schmitz, C. Neuropathological findings in autism. Brain, 2004, 127, 2572-83.

[32] Moreno-Fuenmayor, H.; Borjas, L.; Arrieta, A.; Valera, V.; Socorro-Candanoza, L. Plasma excitatory amino acids in autism. Invest. Clin., 1996, 37, 113-28.

[33] Chugani, D.C.; Sundram, B.S.; Behen, M.; Lee, M.L.; Moore, G.J. Evidence of altered energy metabolism in autistic children. Prog. Neuropsychopharmacol. Biol. Psychiatry, 1999, 23, 635-41.

[34] Fatemi, S.H.; Halt, A.R.; Stary, J.M.; Kanodia, R.; Schulz, S.C.; Realmuto, G.R. Glutamic acid decarboxylase 65 and 67 kDa proteins are reduced in autistic parietal and cerebellar cortices. Biol.
Psychiatry, 2002, 52, 805-10.

[35] Page, L. A.; Daly, E.; Schmitz, N.; Simmons, A.; Toal, F.; Deeley, Q.; Ambery, F.; McAlonan, G. M.; Murphy, K. C.; Murphy, D. G. In vivo $1 \mathrm{H}$-magnetic resonance spectroscopy study of amygdalahippocampal and parietal regions in autism. Am. J. Psychiatry, 2006, 163, 2189-92.

[36] Telfeian, A.E.; Federoff, H.J.; Leone, P.; During, M.J.; Williamson, A. Overexpression of GluR6 in rat hippocampus produces seizures and spontaneous nonsynaptic bursting in vitro. Neurobiol. Dis., 2000, 7, 362-74.

[37] Zhang, H.; Liu, X.; Zhang, C.; Mundo, E.; Macciardi, F.; Grayson, D.R.; Guidotti, A.R.; Holden, J.J. Reelin gene alleles and susceptibility to autism spectrum disorders. Mol. Psychiatry, 2002, 7, 101217.

[38] Yip, J.; Soghomonian, J.J.; Blatt, G.J. Decreased GAD67 mRNA levels in cerebellar Purkinje cells in autism: pathophysiological implications. Acta Neuropathol., 2007, 113, 559-68.

[39] Yip, J.; Soghomonian, J.J.; Blatt, G.J. Increased GAD67 mRNA expression in cerebellar interneurons in autism: implications for Purkinje cell dysfunction. J. Neurosci. Res., 2008, 86, 525-30.

[40] Rigby, M.; Le Bourdelles, B.; Heavens, R.P.; Kelly, S.; Smith, D.; Butler, A.; Hammans, R.; Hills, R.; Xuereb, J.H.; Hill, R.G.; Whiting, P.J.; Sirinathsinghji, D.J. The messenger RNAs for the Nmethyl-D-aspartate receptor subunits show region-specific expression of different subunit composition in the human brain. Neuroscience, 1996, 73, 429-47.

[41] Beattie, E.C.; Carroll, R.C.; Yu, X.; Morishita, W.; Yasuda, H.; von Zastrow, M.; Malenka, R.C. Regulation of AMPA receptor endocytosis by a signaling mechanism shared with LTD. Nat. Neurosci., 2000, 3, 1291-300.

[42] De Blasi, A.; Conn, P.J.; Pin, J.; Nicoletti, F. Molecular determinants of metabotropic glutamate receptor signaling. Trends Pharmacol. Sci., 2001, 22, 114-20.

[43] Lavreysen, H.; Dautzenberg, F.M. Therapeutic Potential of Group III Metabotropic Glutamate Receptors. Curr. Med. Chem., 2008, 15, 671-84.

[44] Novelli, A.; Reilly, J.A.; Lysko, P.G.; Henneberry, R.C. Glutamate becomes neurotoxic via the N-methyl-D-aspartate receptor when intracellular energy levels are reduced. Brain Res.,1988, 451, 20512.

[45] Nicholls, D.G.; Budd, S.L. Mitochondria and neuronal survival. Physiol. Rev., 2000, 80, 315-60.

[46] Dölen, G.; Bear, M.F. Role for metabotropic glutamate receptor 5 (mGluR5) in the pathogenesis of fragile X syndrome. J. Physiol., 2008, 586, 1503-08.

[47] Seal, R.P.; Amara, S.G. Excitatory amino acid transporters: a family in flux. Annu. Rev. Pharmacol. Toxicol., 1999, 39, 431-56.

[48] Furuta, A.; Rothstein, J.D.; Martin, L.J. Glutamate transporter protein subtypes are expressed differentially during rat CNS development. J. Neurosci.,1997, 17, 8363-75.

[49] Tsai, V.W.; Scott, H.L.; Lewis, R.J.; Dodd, P.R. The role of group I metabotropic glutamate receptors in neuronal excitotoxicity in Alzheimer's disease. Neurotox. Res., 2005, 7, 125-41.

[50] Martin-Ruiz, R.; Ugedo, L.; Honrubia, M.A.; Mengod, G.; Artigas, F. Control of serotonergic neurons in rat brain by dopaminergic receptors outside the dorsal raphe nucleus. J. Neurochem., 2001, 77, 762-75.

[51] Olney, J.W. Brain lesions, obesity, and other disturbances in mice treated with monosodium glutamate. Science, 1969, 164, 719-21.

[52] Beal, H.; Hyman, B.T.; Koroshertz, W. Do defects in mitochondrial energy metabolism underlie the pathology of neurodegenerative diseases? Trends Neurosci., 1994, 17, 107-08.

[53] Rothstein, J.D. Excitotoxicity hypothesis. Neurology, 1996, 47, S19-25; discussion S26.

[54] Bar-Peled, O.; Ben-Hur, H.; Biegon, A.; Groner, Y.; Dewhurst, S.; Furuta, A.; Rothstein, J.D. Distribution of glutamate transporter subtypes during human brain development. J. Neurochem., 1997, 69, 2571-80.

[55] Schlett, K. Glutamate as a modulator of embryonic and adult neurogenesis. Curr. Top Med. Chem., 2006, 6, 949-60.

[56] Olney, J.W. New insights and new issues in developmental neurotoxicology. Neurotoxicology, 2002, 23, 659-68.

[57] Marret, S.; Gressens, P.; Evrard, P. Arrest of neuronal migration by excitatory amino acids in hamster developing brain. Proc. Natl. 
Acad. Sci. USA, 1996, 93, 15463-8.

[58] Carper, R.A.; Courchesne, E. Inverse correlation between frontal lobe and cerebellum sizes in children with autism. Brain, 2000, 123 ( Pt 4), 836-44.

[59] Fatemi, S.H.; Halt, A.R.; Realmuto, G.; Earle, J.; Kist, D.A.; Thuras, P.; Merz, A. Purkinje cell size is reduced in cerebellum of patients with autism. Cell Mol. Neurobiol., 2002, 22, 171-5.

[60] Komuro, H.; Yacubova, E. Recent advances in cerebellar granule cell migration. Cell. Mol. Life Sci., 2003, 60, 1084-98.

[61] Komuro, H.; Rakic, P. Modulation of neuronal migration by NMDA receptors. Science, 1993, 260, 95-7.

[62] Komuro, H.; Rakic, P. Orchestration of neuronal migration by activity of ion channels, neurotransmitter receptors, and intracellular Ca2+ fluctuations. J. Neurobiol., 1998, 37, 110-30.

[63] Shen, W.; Slaughter, M.M. A non-excitatory paradigm of glutamate toxicity. J. Neurophysiol., 2002, 87, 1629-34.

[64] D'Aversa, T.G.; Yu, K.O.; Berman, J.W. Expression of chemokines by human fetal microglia after treatment with the human immunodeficiency virus type 1 protein Tat. J. Neurovirol., 2004, 10, 8697.

[65] Farber, K.; Kettenmann, H. Physiology of microglial cells. Brain Res. Brain Res. Rev., 2005, 48, 133-43.

[66] Dziegielewska, K.M.; Moller, J.E.; Potter, A.M.; Ek, J.; Lane, M.A.; Saunders, N.R. Acute-phase cytokines IL-1beta and TNFalpha in brain development. Cell Tissue Res., 2000, 299, 335-45.

[67] Koenig, H.; Trout, J.J.; Goldstone, A.D.; Lu, C.Y. Capillary NMDA receptors regulate blood-brain barrier function and breakdown. Brain Res.,1992, 588, 297-303.

[68] Lagrange, P.; Romero, I.A.; Minn, A.; Revest, P.A. Transendothelial permeability changes induced by free radicals in an in vitro model of the blood-brain barrier. Free Radic. Biol. Med., 1999, 27, 667-72.

[69] Verity, M.A. Oxidative damage and repair in the developing nervous system. Neurotoxicology, 1994, 15, 81-91.

[70] Carlsson, M.L. Hypothesis: is infantile autism a hypoglutamatergic disorder? Relevance of glutamate - serotonin interactions for pharmacotherapy. J. Neural. Transm., 1998, 105, 525-35.

[71] Ben-Ari, Y. Limbic seizure and brain damage produced by kainic acid: mechanisms and relevance to human temporal lobe epilepsy. Neuroscience, 1985, 14, 375-403.

[72] Olney, J.W.; Collins, R.C.; Sloviter, R.S. Excitotoxic mechanisms of epileptic brain damage. Adv. Neurol., 1986, 44, 857-77.

[73] Tuchman, R.F.; Rapin, I. Regression in pervasive developmental disorders: seizures and epileptiform electroencephalogram correlates. Pediatrics, 1997, 99, 560-6.

[74] Meldrum, B.S.; Rogawski, M.A. Molecular targets for antiepileptic drug development. Neurotherapeutics, 2007, 4, 18-61.

[75] Baumeister, F.A.; Gsell, W.; Shin, Y.S.; Egger, J. Glutamate in pyridoxine-dependent epilepsy: neurotoxic glutamate concentration in the cerebrospinal fluid and its normalization by pyridoxine. $P e$ diatrics, 1994, 94, 318-21.

[76] Johnston, M.V. Neurotransmitters and vulnerability of the developing brain. Brain Dev., 1995, 17, 301-6.

[77] Belmonte, M.K.; Allen, G.; Beckel-Mitchener, A.; Boulanger, L.M.; Carper, R.A.; Webb, S.J. Autism and abnormal development of brain connectivity. J. Neurosci., 2004, 24, 9228-31.

[78] Yu, T.; Zhao, Y.; Shi, W.; Ma, R.; Yu, L. Effects of maternal oral administration of monosodium glutamate at a late stage of pregnancy on developing mouse fetal brain. Brain Res., 1997, 747, 195206.

[79] Nacher, J.; McEwen, B.S. The role of N-methyl-D-asparate receptors in neurogenesis. Hippocampus, 2006, 16, 267-70.

[80] Cohly, H.H.; Panja, A. Immunological findings in autism. Int. Rev. Neurobiol., 2005, 71, 317-41.

[81] Ashwood, P.; Wakefield, A.J. Immune activation of peripheral blood and mucosal CD3+ lymphocyte cytokine profiles in children with autism and gastrointestinal symptoms. J. Neuroimmunol., 2006, 173, 126-34.

[82] Ashwood, P.; Wills, S.; Van de Water, J. The immune response in autism: a new frontier for autism research. J. Leukoc. Biol., 2006, $80,1-15$.

[83] Gadient, R.A.; Otten, U. Expression of interleukin-6 (IL-6) and interleukin-6 receptor (IL-6R) mRNAs in rat brain during postnatal development. Brain Res., 1994, 637, 10-14.
[84] Saliba, E.; Henrot, A. Inflammatory mediators and neonatal brain damage. Biol. Neonate, 2001, 79, 224-7.

[85] Vallieres, L.; Campbell, I.L.; Gage, F.H.; Sawchenko, P.E. Reduced hippocampal neurogenesis in adult transgenic mice with chronic astrocytic production of interleukin-6. J. Neurosci., 2002, $22,486-92$.

[86] Ekdahl, C.T.; Claasen, J.H.; Bonde, S.; Kokaia, Z.; Lindvall, O. Inflammation is detrimental for neurogenesis in adult brain. Proc. Natl. Acad. Sci. USA, 2003, 100, 13632-37.

[87] Singh, V.K.; Warren, R.; Averett, R.; Ghaziuddin, M. Circulating autoantibodies to neuronal and glial filament proteins in autism. Pediatr. Neurol., 1997, 17, 88-90.

[88] Singh, V.K.; Lin, S.X.; Newell, E.; Nelson, C. Abnormal measlesmumps-rubella antibodies and CNS autoimmunity in children with autism. J. Biomed. Sci., 2002, 9, 359-64.

[89] Hamberger, A.; Gillberg, C.; Palm, A.; Hagberg, B. Elevated CSF glutamate in Rett syndrome. Neuropediatrics, 1992, 23, 212-3.

[90] Panegyres, P.K.; Hughes, J. The neuroprotective effects of the recombinant interleukin-1 receptor antagonist rhIL-1 ra after excitotoxic stimulation with kainic acid and its relationship to the amyloid precursor protein gene. J. Neurol. Sci., 1998, 154, 123-32.

[91] Zimmerman, A.W.; Jyonouchi, H.; Comi, A.M.; Connors, S.L.; Milstien, S.; Varsou, A.; Heyes, M.P. Cerebrospinal fluid and serum markers of inflammation in autism. Pediatr. Neurol., 2005, 33, 195-201.

[92] Yang, L.; Lindholm, K.; Konishi, Y.; Li, R.; Shen, Y. Target depletion of distinct tumor necrosis factor receptor subtypes reveals hippocampal neuron death and survival through different signal transduction pathways. J. Neurosci., 2002, 22, 3025-32.

[93] Takeuchi, H.; Jin, S.; Wang, J.; Zhang, G.; Kawanokuchi, J.; Kuno, R.; Sonobe, Y.; Mizuno, T.; Suzumura, A. Tumor necrosis factoralpha induces neurotoxicity via glutamate release from hemichannels of activated microglia in an autocrine manner. J. Biol. Chem., 2006, 281, 21362-8.

[94] Qiu, Z.; Sweeney, D.D.; Netzeband, J.G.; Gruol, D.L. Chronic interleukin-6 alters NMDA receptor-mediated membrane responses and enhances neurotoxicity in developing CNS neurons. J. Neurosci., 1998, 18, 10445-56.

[95] Combrinck, M.I.; Perry, V.H.; Cunningham, C. Peripheral infection evokes exaggerated sickness behaviour in pre-clinical murine prion disease. Neuroscience, 2002, 112, 7-11.

[96] Buller, K.M.; Day, T.A. Systemic administration of interleukin1 beta activates select populations of central amygdala afferents. $J$. Comp. Neurol., 2002, 452, 288-96.

[97] Kim, W.G.; Mohney, R.P.; Wilson, B.; Jeohn, G.H.; Liu, B.; Hong, J.S. Regional difference in susceptibility to lipopolysaccharideinduced neurotoxicity in the rat brain: role of microglia. J. Neurosci., 2000, 20, 6309-16.

[98] Perry, V.H.; Newman, T.A.; Cunningham C. The impact of systemic infection on the progression of neurodegenerative disease. Nat. Rev. Neurosci., 2003, 4, 103-12.

[99] Cunningham, C.; Deacon, R.; Wells, H.; Boche, D.; Waters, S.; Diniz, C.P.; Scott, H.; Rawlins, J.N.; Perry, V.H. Synaptic changes characterize early behavioural signs in the ME7 model of murine prion disease. Eur. J. Neurosci., 2003, 17, 2147-55.

[100] Lemstra, A.W.; Groen in't Woud, J.C.; Hoozemans, J.J.; van Haastert, E.S.; Rozemuller, A.J.; Eikelenboom, P.; van Gool, W.A. Microglia activation in sepsis: a case-control study. J. Neuroinflammation, 2007, 4, 4.

[101] Katayama, Y.; Hotta, H.; Nishimura, A.; Tatsuno, Y.; Homma, M. Detection of measles virus nucleoprotein mRNA in autopsied brain tissues. J. Gen. Virol., 1995, 76 ( Pt 12), 3201-4.

[102] Charleston, J.S.; Body, R.L.; Bolender, R.P.; Mottet, N.K.; Vahter M.E.; Burbacher, T.M. Changes in the number of astrocytes and microglia in the thalamus of the monkey Macaca fascicularis following long-term subclinical methylmercury exposure. Neurotoxicology, 1996, 17, 127-38.

[103] Vahter, M.; Akesson, A.; Lind, B.; Bjors, U.; Schutz, A.; Berglund, $M$. Longitudinal study of methylmercury and inorganic mercury in blood and urine of pregnant and lactating women, as well as in umbilical cord blood. Environ. Res., 2000, 84, 186-94.

[104] Burbacher, T.M.; Rodier, P.M.; Weiss, B. Methylmercury developmental neurotoxicity: a comparison of effects in humans and animals. Neurotoxicol. Teratol., 1990, 12, 191-202. 
[105] Burbacher, T.M.; Shen, D.D.; Liberato, N.; Grant, K.S.; Cernichiari, E.; Clarkson, T. Comparison of blood and brain mercury levels in infant monkeys exposed to methylmercury or vaccines containing thimerosal. Environ. Health Perspect., 2005, 113, 1015-21.

[106] Vojdani, A.; Campbell, A.W.; Anyanwu, E.; Kashanian, A.; Bock, K.; Vojdani, E. Antibodies to neuron-specific antigens in children with autism: possible cross-reaction with encephalitogenic proteins from milk, Chlamydia pneumoniae and Streptococcus group A. J. Neuroimmunol., 2002, 129, 168-77.

[107] Vojdani, A.; O'Bryan, T.; Green, J.A.; McCandless, J.; Woeller, K.N.; Vojdani, E.; Nourian, A.A.; Cooper, E.L. Immune response to dietary proteins, gliadin and cerebellar peptides in children with autism. Nutr. Neurosci., 2004, 7, 151-61.

[108] Hida, S.; Miura, N.N.; Adachi, Y.; Ohno, N. Effect of Candida albicans cell wall glucan as adjuvant for induction of autoimmune arthritis in mice. J. Autoimmun., 2005, 25, 93-101.

[109] Hida, S.; Nagi-Miura, N.; Adachi, Y.; Ohno, N. Beta-glucan derived from zymosan acts as an adjuvant for collagen-induced arthritis. Microbiol. Immunol., 2006, 50, 453-61.

[110] Olney, J.W. Glutamate, a neurotoxic transmitter. J. Child Neurol., 1989, 4, 218-26.

[111] Plaitakis, A.; Flessas, P.; Natsiou, A.B.; Shashidharan, P. Glutamate dehydrogenase deficiency in cerebellar degenerations: clinical, biochemical and molecular genetic aspects. Can. J. Neurol. Sci., 1993, 20 Suppl 3, S109-16.

[112] Olney, J.W.; Sharpe, L.G.; Feigin, R.D. Glutamate-induced brain damage in infant primates. J. Neuropathol. Exp. Neurol., 1972, 31, 464-88.

[113] Frieder, B.; Grimm, V.E. Prenatal monosodium glutamate (MSG) treatment given through the mother's diet causes behavioral deficits in rat offspring. Int. J. Neurosci., 1984, 23, 117-26.

[114] Frieder, B.; Grimm, V.E. Prenatal monosodium glutamate causes long-lasting cholinergic and adrenergic changes in various brain regions. J. Neurochem.,1987, 48, 1359-65.

[115] Sakamoto, M.; Nakano, A. Comparison of mercury accumulation among the brain, liver, kidney, and the brain regions of rats administered methylmercury in various phases of postnatal development. Bull. Environ. Contam. Toxicol., 1995, 55, 588-96.

[116] Mitani, A.; Watanabe, M.; Kataoka, K. Functional change of NMDA receptors related to enhancement of susceptibility to neurotoxicity in the developing pontine nucleus. J. Neurosci.,1998, 18, 7941-52.

[117] Bawari, M.; Babu, G.N.; Ali, M.M.; Misra, U.K. Effect of neonatal monosodium glutamate on lipid peroxidation in adult rat brain. Neuroreport, 1995, 6, 650-2.

[118] Singh, K.; Ahluwalia, P. Studies on the effect of monosodium glutamate [MSG] administration on some antioxidant enzymes in the arterial tissue of adult male mice. J. Nutr. Sci.Vitaminol. (Tokyo), 2003, 49, 145-8.

[119] Martinez-Contreras, A.; Huerta, M.; Lopez-Perez, S.; GarciaEstrada, J.; Luquin, S.; Beas Zarate, C. Astrocytic and microglia cells reactivity induced by neonatal administration of glutamate in cerebral cortex of the adult rats. J. Neurosci. Res., 2002, 67, 20010 .

[120] Beas-Zarate, C.; Perez-Vega, M.; Gonzalez-Burgos, I. Neonatal exposure to monosodium L-glutamate induces loss of neurons and cytoarchitectural alterations in hippocampal CA1 pyramidal neurons of adult rats. Brain Res., 2002, 952, 275-81.

[121] Kubo, T.; Kohira, R.; Okano, T.; Ishikawa, K. Neonatal glutamate can destroy the hippocampal CA1 structure and impair discrimination learning in rats. Brain Res., 1993, 616, 311-4.

[122] Wong, P.T.; Neo, L.H.; Teo, W.L.; Feng, H.; Xue, Y.D.; Loke, W.H. Deficits in water escape performance and alterations in hippocampal cholinergic mechanisms associated with neonatal monosodium glutamate treatment in mice. Pharmacol. Biochem. Behav., 1997, 57, 383-8.

[123] Dubovicky, M.; Tokarev, D.; Skultetyova, I.; Jezova, D. Changes of exploratory behaviour and its habituation in rats neonatally treated with monosodium glutamate. Pharmacol. Biochem. Behav., 1997, 56, 565-9.

[124] Yan, H.D.; Ji-qun, C.; Ishihara, K.; Nagayama, T.; Serikawa, T.; Sasa, M. Separation of antiepileptogenic and antiseizure effects of levetiracetam in the spontaneously epileptic rat (SER). Epilepsia, 2005, 46, 1170-7.
[125] Wilson, B.M.; Cox, C.L. Absence of metabotropic glutamate receptor-mediated plasticity in the neocortex of fragile $\mathrm{X}$ mice. Proc. Natl. Acad. Sci. USA, 2007, 104, 2454-9.

[126] Chang, S.; Bray, S.M.; Li, Z.; Zarnescu, D.C.; He, C.; Jin, P.; Warren, S.T. Identification of small molecules rescuing fragile $\mathrm{X}$ syndrome phenotypes in Drosophila. Nat. Chem. Biol., 2008, 4, 256-63.

[127] Geier, D.A.; Geier, M.R. A clinical trial of combined anti-androgen and anti-heavy metal therapy in autistic disorders. Neuroendocrinol. Lett., 2006, 27, 833-8.

[128] Geier, D.A.; Geier, M.R. A prospective assessment of porphyrins in autistic disorders: a potential marker for heavy metal exposure. Neurotox. Res., 2006, 10, 57-64.

[129] Sager, P.R.; Aschner, M.; Rodier, P.M. Persistent, differential alterations in developing cerebellar cortex of male and female mice after methylmercury exposure. Brain Res.,1984, 314, 1-11.

[130] Choi, B.H. The effects of methylmercury on the developing brain. Prog. Neurobiol., 1989, 32, 447-70.

[131] Park, S.T.; Lim, K.T.; Chung, Y.T.; Kim, S.U. Methylmercuryinduced neurotoxicity in cerebral neuron culture is blocked by antioxidants and NMDA receptor antagonists. Neurotoxicology, 1996, 17, 37-45.

[132] Miyamoto, K.; Nakanishi, H.; Moriguchi, S.; Fukuyama, N.; Eto, K.; Wakamiya, J.; Murao, K.; Arimura, K.; Osame, M. Involvement of enhanced sensitivity of N-methyl-D-aspartate receptors in vulnerability of developing cortical neurons to methylmercury neurotoxicity. Brain Res., 2001, 901, 252-8.

[133] Sorg, O.; Schilter, B.; Honegger, P.; Monnet-Tschudi, F. Increased vulnerability of neurones and glial cells to low concentrations of methylmercury in a prooxidant situation. Acta Neuropathol., 1998, 96, 621-7.

[134] Behan, W.M.; Stone, T.W. Enhanced neuronal damage by coadministration of quinolinic acid and free radicals, and protection by adenosine A2A receptor antagonists. Br. J. Pharmacol., 2002, 135, 1435-42.

[135] Chauhan, A.; Chauhan, V.; Brown, W.T.; Cohen, I. Oxidative stress in autism: increased lipid peroxidation and reduced serum levels of ceruloplasmin and transferrin--the antioxidant proteins. Life Sci., 2004, 75, 2539-49.

[136] Ming, X.; Stein, T.P.; Brimacombe, M.; Johnson,W.G.; Lambert, G.H.; Wagner, G.C. Increased excretion of a lipid peroxidation biomarker in autism. Prostaglandins Leukot. Essent. Fatty Acids, 2005, 73, 379-84.

[137] Brown, G.C.; Bal-Price, A. Inflammatory neurodegeneration mediated by nitric oxide, glutamate, and mitochondria. Mol. Neurobiol., 2003, 27, 325-55.

[138] Hornig, M.; Chian, D.; Lipkin, W.I. Neurotoxic effects of postnatal thimerosal are mouse strain dependent. Mol. Psychiatry, 2004, 9, 833-45.

[139] Brookes, N. Specificity and reversibility of the inhibition by $\mathrm{HgCl} 2$ of glutamate transport in astrocyte cultures. J. Neurochem., 1988, 50, 1117-22.

[140] Inage, Y.W.; Itoh, M.; Wada, K.; Takashima, S. Expression of two glutamate transporters, GLAST and EAAT4, in the human cerebellum: their correlation in development and neonatal hypoxicischemic damage. J. Neuropathol. Exp. Neurol., 1998, 57, 554-62.

[141] Juarez, B.I.; Martinez, M.L.; Montante, M.; Dufour, L.; Garcia, E.; Jimenez-Capdeville, M.E. Methylmercury increases glutamate extracellular levels in frontal cortex of awake rats. Neurotoxicol. Teratol., 2002, 24, 767-71.

[142] Ou, Y.C.; White, C.C.; Krejsa, C.M.; Ponce, R.A.; Kavanagh, T.J.; Faustman, E.M. The role of intracellular glutathione in methylmercury-induced toxicity in embryonic neuronal cells. Neurotoxicology, 1999, 20, 793-804.

[143] Shanker, G.; Syversen, T.; Aschner, J.L.; Aschner, M. Modulatory effect of glutathione status and antioxidants on methylmercuryinduced free radical formation in primary cultures of cerebral astrocytes. Brain Res. Mol. Brain Res., 2005, 137, 11-22.

[144] Yokel, R.A.; Florence, R.L. Aluminum bioavailability from the approved food additive leavening agent acidic sodium aluminum phosphate, incorporated into a baked good, is lower than from water. Toxicology, 2006, 227, 86-93.

[145] Speerhas, R.A.; Seidner, D.L. Measured versus estimated aluminum content of parenteral nutrient solutions. Am. J. Health Syst. 
Pharm., 2007, 64, 740-6.

[146] Campbell, A. The role of aluminum and copper on neuroinflammation and Alzheimer's disease. J. Alzheimers Dis., 2006, 10, 165-72.

[147] Savory, J.; Herman, M.M.; Ghribi, O. Mechanisms of aluminuminduced neurodegeneration in animals: Implications for Alzheimer's disease. J. Alzheimers Dis., 2006, 10, 135-44.

[148] Mundy, W.R.; Freudenrich, T.M.; Kodavanti, P.R. Aluminum potentiates glutamate-induced calcium accumulation and ironinduced oxygen free radical formation in primary neuronal cultures. Mol. Chem. Neuropathol., 1997, 32, 41-57.

[149] Mullenix, P.J.; Denbesten, P.K.; Schunior, A.; Kernan, W.J. Neurotoxicity of sodium fluoride in rats. Neurotoxicol. Teratol., 1995, 17, $169-77$.

[150] Strunecka, A.; Strunecky O.; Patocka J. Fluoride plus aluminum: useful tools in laboratory investigations, but messengers of false information. Physiol. Res., 2002, 51, 557-64.

[151] Strunecka, A.; Patocka, J.; Blaylock, R.L.; Chinoy, N.J. Fluoride interactions: From molecules to disease. Curr. Signal Transd. Ther., 2007, 2, 190-213.

[152] Luke, J. Fluoride deposition in the aged human pineal gland. Caries Res., 2001, 35, 125-8.

[153] Tordjman, S.; Anderson, G.M.; Pichard, N.; Charbuy, H.; Touitou, Y. Nocturnal excretion of 6-sulphatoxymelatonin in children and adolescents with autistic disorder. Biol. Psychiatry, 2005, 57, 1348 .

[154] Pandi-Perumal, S.R.; Smits, M.; Spence, W.; Srinivasan, V.; Cardinali, D.P.; Lowe, A.D.; Kayumov, L. Dim light melatonin onset (DLMO): a tool for the analysis of circadian phase in human sleep and chronobiological disorders. Prog. Neuropsychopharmacol. Biol. Psychiatry, 2007, 31, 1-11.

[155] Tauman, R.; Zisapel, N.; Laudon, M.; Nehama, H.; Sivan, Y. Melatonin production in infants. Pediatr. Neurol., 2002, 26, 37982

[156] Stigler, K.A.; Desmond, L.A.; Posey, D.J.; Wiegand, R.E.; McDougle, C.J. A naturalistic retrospective analysis of psychostimulants in pervasive developmental disorders. J. Child Adolesc. Psychopharmacol., 2004, 14, 49-56.

[157] Belsito, K.M.; Law, P.A.; Kirk, K.S.; Landa, R.J.; Zimmerman, A.W. Lamotrigine therapy for autistic disorder: a randomized, double-blind, placebo-controlled trial. J. Autism Dev. Disord., 2001, $31,175-81$.

[158] Erickson, C.A.; Posey, D.J.; Stigler, K.A.; Mullett, J.; Katschke, A.R.; McDougle, C.J. A retrospective study of memantine in children and adolescents with pervasive developmental disorders. Psychopharmacology (Berl)., 2007, 191, 141-7.

[159] Mazza, M.; Pomponi, M.; Janiri, L.; Bria, P.; Mazza, S. Omega-3 fatty acids and antioxidants in neurological and psychiatric diseases: an overview. Prog. Neuropsychopharmacol. Biol. Psychiatry, 2007, 31, 12-26.

[160] Bourre, J.M. Effects of nutrients (in food) on the structure and function of the nervous system: update on dietary requirements for brain. Part 1: micronutrients. J. Nutr. Health Aging, 2006, 10, 37785 .

[161] Filipek, P.A.; Juranek, J.; Nguyen, M.T.; Cummings, C.; Gargus, J.J. Relative carnitine deficiency in autism. J. Autism Dev. Disord., 2004, 34, 615-23.

[162] Wong, H.H.; Smith, R.G. Patterns of complementary and alternative medical therapy use in children diagnosed with autism spectrum disorders. J. Autism Dev. Disord., 2006, 36, 901-9.

[163] Jones, T.W.; Borg, W.P.; Boulware, S.D.; McCarthy, G.; Sherwin, R.S.; Tamborlane, W.V. Enhanced adrenomedullary response and increased susceptibility to neuroglycopenia: mechanisms underlying the adverse effects of sugar ingestion in healthy children. J. Pediatr., 1995, 126, 171-7.
[164] Dolske, M.C.; Spollen, J.; McKay, S.; Lancashire, E.; Tolbert, L. A preliminary trial of ascorbic acid as supplemental therapy for autism. Prog. Neuropsychopharmacol. Biol. Psychiatry, 1993, 17, 765-74.

[165] Kheir-Eldin, A.A.; Motawi, T.K.; Gad, M.Z.; Abd-ElGawad, H.M. Protective effect of vitamin E, beta-carotene and $\mathrm{N}$-acetylcysteine from the brain oxidative stress induced in rats by lipopolysaccharide. Int. J. Biochem. Cell Biol., 2001, 33, 475-82.

[166] Akaike, A.; Tamura, Y.; Sato, Y.; Yokota, T. Protective effects of a vitamin B12 analog, methylcobalamin, against glutamate cytotoxicity in cultured cortical neurons. Eur. J. Pharmacol., 1993, 241, 1-6.

[167] Rimland, B. High dose vitamin B6 and magnesium in treating autism: response to study by Findling et al. J. Autism Dev. Disord.,1998, 28, 581-2

[168] Eyles, D.W.; Smith, S.; Kinobe, R.; Hewison, M.; McGrath, J.J. Distribution of the vitamin D receptor and 1 alpha-hydroxylase in human brain. J. Chem. Neuroanat., 2005, 29, 21-30.

[169] Taniura, H.; Ito, M.; Sanada, N.; Kuramoto, N.; Ohno, Y.; Nakamichi, N.; Yoneda, Y. Chronic vitamin D3 treatment protects against neurotoxicity by glutamate in association with upregulation of vitamin D receptor mRNA expression in cultured rat cortical neurons. J. Neurosci. Res., 2006, 83, 1179-89.

[170] Cannell, J.J. Autism and vitamin D. Med. Hypotheses, 2008, 70, 750-9.

[171] Lainhart, J.E.; Bigler, E.D.; Bocian, M.; Coon, H.; Dinh, E.; Dawson, G.; Deutsch, C.K.; Dunn, M.; Estes, A.; Tager-Flusberg, H.; Folstein, S.; Hepburn, S.; Hyman, S.; McMahon, W.; Minshew, N.; Munson, J.; Osann, K.; Ozonoff, S.; Rodier, P.; Rogers, S.; Sigman, M.; Spence, M.A.; Stodgell, C.J.; Volkmar, F. Head circumference and height in autism: a study by the Collaborative Program of Excellence in Autism. Am. J. Med. Genet. A., 2006, 140, 225774.

[172] Neveu, I.; Naveilhan, P.; Menaa, C.; Wion, D.; Brachet, P.; Garabedian, M. Synthesis of 1,25-dihydroxyvitamin D3 by rat brain macrophages in vitro. J. Neurosci. Res., 1994, 38, 214-20.

[173] Lefebvre d'Hellencourt, C.; Montero-Menei, C.N.; Bernard, R.; Couez, D. Vitamin D3 inhibits proinflammatory cytokines and nitric oxide production by the EOC13 microglial cell line. J. Neurosci. Res., 2003, 71, 575-82.

[174] Nataf, S.; Garcion, E.; Darcy, F.; Chabannes, D.; Muller, J.Y; Brachet, P. 1,25 Dihydroxyvitamin D3 exerts regional effects in the central nervous system during experimental allergic encephalomyelitis. J. Neuropathol. Exp. Neurol., 1996, 55, 904-14.

[175] Cantorna, M.T.; Hayes, C.E.; DeLuca, H.F. 1,25-Dihydroxyvitamin D3 reversibly blocks the progression of relapsing encephalomyelitis, a model of multiple sclerosis. Proc. Natl. Acad. Sci. USA, 1996, 93, 7861-4.

[176] Cantorna, M.T.; Zhu, Y.; Froicu, M.; Wittke, A. Vitamin D status, 1,25-dihydroxyvitamin D3, and the immune system. Am. J. Clin. Nutr., 2004, 80, 1717S-20S.

[177] Wang, Y.; Chiang, Y.H.; Su, T.P.; Hayashi, T.; Morales, M.; Hoffer, B.J.; Lin, S.Z. Vitamin D(3) attenuates cortical infarction induced by middle cerebral arterial ligation in rats. Neuropharmacology, 2000, 39, 873-80.

[178] Blaylock, R.L. Phytonutrients and metabolic stimulants as protection against neurodegeneration and excitotoxicity. JAMA, 2000, 2, $30-41$.

[179] Garstang, J.; Wallis, M. Randomized controlled trial of melatonin for children with autistic spectrum disorders and sleep problems. Child Care Health Dev., 2006, 32, 585-9.

[180] Anderson, G.M. The potential role for emergence in autism. Autism Res., 2008, 1, 18-30. 